\title{
When Employee Performance Affects the Quality and Quantity of the Company: What is the Role of Work Discipline and Occupational Safety and Health (OSH)?
}

\author{
B. Lena Nuryanti ${ }^{1, *}$ Masharyono Masharyono ${ }^{2}$ Muhammad Faishal ${ }^{3}$ \\ ${ }^{1}$ Universitas Pendidikan Indonesia \\ ${ }^{2}$ Universitas Pendidikan Indonesia \\ ${ }^{3}$ Universitas Pendidikan Indonesia \\ "Corresponding author. Email: l.nuryanti@gmail.com
}

\begin{abstract}
The crisis of employee performance is a critical problem faced by management in the company. Employee performance problems are still widely faced by companies in various sectors in many countries, both engaged in the public and private sectors, in health institutions, education, banking, state-owned companies, to small companies. The low intensity and inaccessibility of work targets is due to the low quality of human resource performance. Performance is a real behavior that is shown by every employee must be in accordance with their role in the company. The impact of low employee performance is the quality and quantity of work produced is less satisfactory and the creativity of employees is low. This happened to the company PT Kereta Api Indonesia (Persero) Daop 2 Bandung where the level of employee performance has decreased every year, especially in 2016-2018. Surely this is far from the expectations of companies that want their employees to have good performance. This study aims to determine the effect of work discipline and occupational safety and health ( $\mathrm{OSH})$ on employee performance. This study useD a quantitative method involving 45 respondents using saturated sampling with data collection techniques using questionnaires. The data analysis technique used was multiple linear regression. 1) The results of this study indicated that the influence of work discipline was by $16.2 \%$ on employee performance, 2) while occupational safety and health (OSH) had an effect by $20.07 \%$ on employee performance, 3 ) the effect of work discipline in occupational safety and health $(\mathrm{OSH})$ on employee performance was by $34.4 \%$ This shows that the better work discipline and occupational safety and health $(\mathrm{OSH})$, the higher the employee's performance. This means that if work discipline and occupational safety and health are good, optimal work output will be obtained, so that employee performance can improve properly.
\end{abstract}

Keywords: Work Discipline, Occupational Safety and Health (OSH), Employee Performance.

\section{INTRODUCTION}

The issue of human resources is currently still the center of attention for a company to survive in the era of globalization in the face of the ASEAN Economic Community (AEC) [1]. Innovation in the public sector is considered important because it is considered as the main predecessor of public sector performance in facing the challenge of providing better services for human resources [2]. However, [3] argued that the policy in economic development in the world is by improving infrastructure in the public and private sectors that are intended to stimulate economic growth and development in the field of transportation, especially in the railroad industry. Means of transportation is one of the things that is very important in facilitating the success of regional development that can support all economic activities carried out by the community [4]. Because of rapid economic development and global competition, human resource management (HR) has become an important factor to advance the competitiveness of companies [5]. Human resources are the most important assets in the organization because they play a role in achieving organizational goals [6]. Organizations without good human resources in terms of strategy and operations will 
not be able to maintain and achieve organizational goals [7].

The phenomenon of employee performance is a multidimensional construction and criteria that are vital for determining organizational success [8]. Employees who work according to their ability and in accordance with their relative position will work well. If the individual's performance is good then the company's performance will be good [6].

Performance issues are still a topic of problems in HRM research as conducted by [9] regarding employee performance in the manufacturing industry. It was revealed that employees are an inseparable part of human resource management. The crisis of employee performance is a critical problem faced by management in the company [10]. Performance is a real behavior that is shown by every employee must be in accordance with his role in the company. The impact of low employee performance is the quality and quantity of work produced is less satisfactory and the creativity of employees is low [11].

One of the public sectors that is experiencing performance problems is the State-Owned Enterprise (BUMN), which is a government-owned body that competes with the business world. Based on its type, BUMN companies can be categorized as a corporate company (Persero), a public company (Perum), and a bureau company (Perjan), although the form of Perjan is then abolished. Every BUMN company will try to achieve the BUMN establishment goal based on Law Number 19 of 2003, namely "Become a professional BUMN to increase the value of BUMN". One important factor in the success of BUMN in achieving its goals is quality human resources and good management of human resources in order to obtain optimal performance.

The problem that often arises in companies today is the lack of attention to the human aspect [12]. Companies need an employee who has high performance and can support the achievement of goals and objectives set by the company [13]. Every company tends to provide performance appraisal that is not in accordance with the facts in the field [14], so the performance measurement needed to be able to know the extent of the existence, role and contribution of human resources in achieving success becomes less effective [15].

The performance of the employees of PT Kereta Api Indonesia (Persero) Daop 2 Bandung has decreased. Where the results of performance appraisal in 2016 in the category were quite good, then in 2017 it has increased, so that it became in a good category and for 2018 employee performance decreased again to be categorized as quite good. Surely this is far from the expectations of companies that want their employees to have good performance.
Employee performance is very important to be continuously improved so that the organization can achieve its goals [10]. The human resource factor plays the most important and main role in the production process because the means of production will not run without the support and presence of human resources [12].

The company's performance is said to have quality and success in achieving its goals can be influenced by factors originating from within the company such as work discipline, employee education, and training in accordance with the ability of employees to complete their duties and responsibilities, so as to produce quality output [16]. Work discipline is very important because if employees have work discipline, it will produce quality work, quantity of work and good working time so that it can improve employee performance [13].

Work discipline owned by employees can affect employee performance [17]. One of the results of research conducted by [18] in the manufacturing industry showed that employee performance was relatively low marked by increased employee absences, but there were still ways to improve it. Achievement of employee performance can be through the assessment of employee work discipline as an attitude of willingness and willingness to obey the applicable regulatory norms around it [1]. There was a fluctuation in the level of PT Kereta Api Indonesia (Persero) Daop 2 Bandung from 2014-2018. Several employees said that the thing that made them late was force mejeure factors (conditions beyond human capability) such as rain, traffic jams, sick families and sick employees themselves. So that aspects of work discipline related to order and timeliness become a challenge for companies and employees [19]. By looking at the level of employee delay, the company can measure employee performance, so the company can evaluate what actions can reduce the level of employee delay.

Work discipline will encourage employees not to take actions that can harm the company [20]. [21] stated that enriching discipline can improve employees' innovation at work. Improving employee work discipline needs good work facilities because work facilities are a form of company service for employees to support performance in meeting employee needs, so as to increase employee productivity [12].

The factors that affect performance include compensation, work environment, work culture, motivation, work discipline, work ability and occupational safety and health (OSH) [15]. Reference [22] stated that employee performance is influenced by employee intrinsic and extrinsic factors. Intrinsic factors that affect employee performance consist of education, experience, motivation, health, age, skills, emotions and spirituality. While the extrinsic factors that affect employee performance consist of physical and non- 
physical environment, leadership, vertical and horizontal communication, compensation, facilities, training, workload, work procedures, punishment systems and so on.

The majority of previous research on occupational safety and health facility planning has focused on optimizing costs and proximity relationships [23]. However, most of the literature has examined health and safety issues in relation to work [24] such as research conducted by [25]. One way to improve the performance of employees trying to do railway operational safety in realizing railroad operations towards zero accidents and transportation safety management needs to be done systematically and sustainably. The record of the Directorate General of Railways of the Ministry of Transportation, excluding external factors, causes of train accidents were dominated by human error operators with a percentage of $25 \%$, followed by facilities, $24 \%$, infrastructure $15 \%$, and nature $7 \%$. The human error factor in train accidents is often considered to be just machinists' error, but it needs further investigation because human error that occurs is a contribution from other aspects such as management, systems, etc [26].

Many developed countries have a comprehensive occupational health and safety (OHSAS) management system that ensures a continuous decline in the rates of workplace accidents [27]. The OSH processes comprise strategies, policies and measures implemented with a view to improving employees OSH [28]. Since 2012, PT Kereta Api Indonesia (Persero) has issued policies related to OSH in the form of safety commitments, decrees and directors' instructions related to occupational safety and health (OSH). In the application of OHSAS (Occupational Safety and Health Management System), PT Kereta Api Indonesia (Persero) requires all employees to comply with standard operating policies and procedures related to occupational safety and health to minimize the occurrence of incidents, work accidents, near misses, and occupational diseases. In addition, each employee must create and maintain cleanliness, safety and comfort of the work environment, wear personal protective equipment and work safety equipment according to the requirements and not taking unsafe actions that can cause work accidents and occupational diseases.

Based on Law Number 13 of 2003 concerning employment and Government regulation Number 50 of 2012 concerning the implementation of an occupational safety and health management system, PT Kereta Api Indonesia (Persero) is required to implement an occupational safety and health management system (OHSAS). PT Kereta Api Indonesia (Persero) always puts forward the principles of occupational safety and health $(\mathrm{OSH})$ in all aspects of its activities. To emphasize the OSH culture at PT Kereta Api Indonesia (Persero) a special work unit handles OSH which is responsible to the Director of safety and security. Occupational safety and health (OSH) is an absolute matter to be considered by all employees of PT Kereta Api Indonesia (Persero) because it is the main pillar of the company.

The development of a company is very dependent on the performance of its employees. Occupational safety and health $(\mathrm{OSH})$ is one of the basic rights for every employee [29]. So that employees work with full responsibility to achieve good employee performance [30].

Reference [31] stated that human resource management (HRM) is the use of individuals to achieve organizational goals. Basically, all managers get things done through the efforts of others. As a result, managers at every level must pay attention to HRM. Individuals who deal with human resource problems face many challenges, ranging from a constantly changing workforce to ever-present government regulations, technological revolutions, and the world. Reference [32] argued that human resource management is the managerial utilization of the effort, knowledge, abilities and behavior of people who contribute to human companies that are authoritatively coordinated as part of a work exchange (or temporary contractual arrangement) to carry out work tasks in a way which allows the company to continue into the future. According to [33], human resource management is one area of general management which includes aspects of planning, organizing, implementing, and controlling. This process exists in the functions/fields of production, marketing, finance and employees.

Based on the explanation of the HRM definition previously explained, it can be said that human resource management is a science that regulates the process of utilizing labor so that it can run well in accordance with existing procedures in order to produce good performance and achieve company goals.

According to [31], people involved in HR management develop and work through integrated human resource management systems. There are six functional areas associated with effective human resource management including 1) staffing, 2) performance management, 3) human resource development, 4) compensation, 5) employee and labor relations, 6) sefty and health.

Reference [31] stated that employee and labor relations consist of human resource management activities related to the movement of employees within the company and the relationship between employees and employers within the company. Such topics include discipline, dismissal, demotion, downsizing, transfer, promotion, resignation, and retirement.

Reference [31] suggested that discipline is a state of employee self-control and orderly behavior that shows the level of teamwork in an organization. An aspect of 
internal employment that is necessary but often tried is the application of disciplinary action, which requires penalties against employees who fail to meet established standards. Reference [33] suggested that work discipline is a tool used by managers to communicate with employees so that they are willing to change a behavior and as an effort to increase awareness and willingness to obey all company rules and prevailing social norms. An employee is said to have high work discipline if the person concerned is consistent, obedient to the principle, and responsible for the tasks assigned to him.

Based on the understanding described earlier, it can be said that what is meant by work discipline is a mental attitude that is reflected in the actions of individuals or groups in the form of compliance or compliance with regulations established to reinforce organizational guidelines in order to achieve company goals and if the rules are violated, there will be a sanction that has been set. This is expected to reduce the poor performance of the inside of a unit within the company.

Reference [33] explained that the dimensions of work discipline are as follows: 1) presence, 2) compliance with work regulations, 3) compliance with work standards, 4) high level of vigilance, 5) ethical work.

Reference [34] argued that the dimensions of work discipline are as follows: 1) obedience to the rules of time: judging from the hours of coming to work, hours of return, and hours of rest on time in accordance with applicable regulations in the company 2) obedience to company regulations: basic rules on how to dress and behave at work 3) obey the rules of behavior at work: shown by ways of doing work in accordance with the position, duties and responsibilities and how to deal with other work units 4) obey the other rules in the company: rules about what can be done and what should not be done in the company.

According to [31], safety involves protecting employees from injuries resulting from work accidents. Health refers to the freedom of employees from physical or emotional illness. This aspect of work is important because employees who work in a safe environment and enjoy good health are more likely to be productive and produce long-term benefits for the organization. Reference [31] define occupational safety and health as conditions and factors that influence or affect the safety and health of workers (including contract workers), guests or others at work. According to [35] occupational safety and health (OSH) is a protection effort that is proposed to all potentials that can cause danger. It is intended that workers and other people in the workplace are always in a safe and healthy condition and all sources of production can be used safely and efficiently. Based on the above definition, it can be concluded that occupational safety and health is a program that guarantees the safety and health of employees at work.
Reference [31] stated that the dimensions of occupational safety and health include ergonomics, namely the process of designing workplaces to support the abilities of people and jobs or the demands of work.

Reference [36] said that performance is the result of work related to organizational goals such as quality, efficiency, and other criteria of effectiveness. This means that the quality of work is produced well and the right efficiency can show a good performance obtained by the company. Reference [37] stated that employee performance can be interpreted as the value of an employee's work on various matters related to his work, such as abilities, deficiencies, fatigue and potential that he has, which in turn is useful to determine the goals, paths, plans and career development in question. Based on some of the above understanding, it can be said that performance is the result of work that is produced by the ability of individuals or groups carried out based on the skills, experience, sincerity and time to the maximum.

According to [31] the dimensions of performance include 1) quality of work, 2) quantity of work, 3) cooperation, 4) initiative, 5) leadership responsibilities, and 6) ability to make decisions.

Reference [38] suggested that the performance dimensions consist of 1) quality of work, 2) quantity of work performed, 3) interpersonal effectiveness.

According to [35] factors that affect performance include 1) quality and ability of employees, namely matters related to education/ training, work ethic, work motivation, mental attitude, and physical condition of employees 2) supporting facilities, i.e. matters related to the work environment (occupational safety, occupational health, production facilities, technology) and matters related to employee welfare (wages/salaries, social security, job security) 3) supra facilities, namely things relating to government policies and industrial relations management. Reference [33] explains that employee performance is influenced by several factors, namely: 1) expectations about rewards, 2) encouragement, 3) ability, needs, and nature, 4) perception of tasks, 5) internal and external rewards, and 6 ) perception of the level of benefits and job satisfaction.

\section{METHODS}

This study was conducted to obtain 1) the effect of work discipline on employee performance, 2) the effect of occupational safety and health (OSH) on employee performance, 3) the effect of work discipline and occupational safety and health $(\mathrm{OSH})$ on the performance of employees of PT Kereta Api Indonesia (Persero) Daop 2 Bandung. This research was verification. research conducted in a period of 5 months, starting from March 2018 to August 2018. The research period used was a cross sectional method. In this study, the population and sample were 45 employees of PT. Kereta Api Indonesia 
(Persero) Daop 2 Bandung, in the operational division of the Bandung station. The analysis technique used in this study was multiple regression and hypothesis testing used was the t-test (partial significance test) and F-test (simultaneous significance test).

\section{RESULTS AND DISCUSSION}

After knowing the value of $\mathrm{R}$ Square, the coefficient of determination can be calculated using (1).

$$
\mathrm{CD}=\mathrm{r}^{2} \times 100
$$

Information:

$$
\begin{aligned}
& \mathrm{CD}=\text { Coefficient of Determination } \\
& \mathrm{r}^{2}=\text { Correlation coefficient }
\end{aligned}
$$

Based on Table 1 it can be seen that $\mathrm{R}$ Square for

\begin{tabular}{|c|c|c|c|c|}
\hline \multicolumn{5}{|c|}{ Model Summary } \\
\hline Model & $\boldsymbol{R}$ & R Square & $\begin{array}{l}\text { Adjusted } R \\
\text { Square }\end{array}$ & $\begin{array}{c}\text { Std. Error of the } \\
\text { Estimate }\end{array}$ \\
\hline $\begin{array}{l}\text { Work } \\
\text { Discipline }\end{array}$ & $.402^{\mathrm{a}}$ & .162 & .142 & 23.750 \\
\hline
\end{tabular}
Work Discipline is 0.16 .

Table 1. Partially Determination Coefficient

Dependent Variabel: Employee Performance

Predictors (constant): Work Discipline

Based on Table 2 it can be seen that $\mathrm{R}$ for Occupational Safety and Health is 0.448 .

Table 2. Partially Determination Coefficient

\begin{tabular}{|l|c|l|l|l|}
\hline \multicolumn{5}{|c|}{ Model Summary } \\
\hline \multicolumn{1}{|c|}{ Model } & $\boldsymbol{R}$ & $\boldsymbol{R}$ Square & $\begin{array}{c}\text { Adjusted } \boldsymbol{R} \\
\text { Square }\end{array}$ & $\begin{array}{l}\text { Std. Error of } \\
\text { the Estimate }\end{array}$ \\
\hline $\begin{array}{l}\text { Occupational } \\
\text { Safety and } \\
\text { Health }\end{array}$ & .448a & .201 & .182 & 23.193 \\
\hline
\end{tabular}

Dependent Variabel: Employee performance

Predictors (constant) : Occupational Safety and Health

Then, the magnitude of the influence of Work Discipline on Employee Performance and the magnitude of the influence of Work Discipline on Employee Performance are as follows.

Effect of Work Discipline on Employee Performance

$$
\begin{aligned}
\mathrm{CD} & =(0,402)^{2} \times 100 \% \\
& =16,2 \%
\end{aligned}
$$

Effect of Occupational Safety and Health (OSH) on Employee Performance

$$
\begin{aligned}
\mathrm{CD} & =(0,448)^{2} \times 100 \% \\
& =20,1 \%
\end{aligned}
$$

The amount of influence partially between each variable and the influence of Work Discipline on
Employee Performance is by $16.16 \%$ and the effect of Occupational Safety and Health on Employee Performance is by $20.1 \%$. While the remaining $63.7 \%$ is influenced by other factors that are ignored in this study. According to [35] factors that affect performance include:

- Quality and ability of employees namely matters related to education / training, work ethic, work motivation, mental attitude, and physical condition of employees.

- Supporting facilities, namely matters related to the work environment (work safety, occupational health, production facilities, technology) and matters related to employee welfare (wages/salaries, social security, work security)

- Supra facilities, namely matters related to government policies and industrial relations management.

Based on table 3 it can be seen coefficient of determination score of $34.4 \%$ indicates that work discipline and occupational health and safety (OSH) have a simultaneous influence (together) of $34.4 \%$ on employee performance, while the remaining $65.6 \%$ is influenced by other factors ignored in this study. According to [34], employee performance was

\begin{tabular}{|c|c|c|c|c|}
\hline \multicolumn{5}{|c|}{ Model Summary } \\
\hline Model & $R$ & R Square & $\begin{array}{l}\text { Adjusted } R \\
\text { Square }\end{array}$ & $\begin{array}{c}\text { Std. Error of the } \\
\text { Estimate }\end{array}$ \\
\hline L &, $587^{\mathrm{a}}$ & 344 & 313 & 2,259 \\
\hline
\end{tabular}
influenced by several factors, namely: 1) expectations about rewards, 2) encouragement, 3) ability, needs, and nature, 4) perception of tasks, 5) internal and external rewards, and 6) perception of the level of reward and job satisfaction.

Table 3. Simultaneous Determination Coefficient

Predictors: (Constant), work discipline, occupational safety and health

Dependent Variable: employee performance

$$
\begin{aligned}
\mathrm{CD} & =(0,587)^{2} \times 100 \% \\
& =34,4 \%
\end{aligned}
$$

To find out the percentage of the effect of work discipline on employee performance and occupational safety and health $(\mathrm{OSH})$ on employee performance, the SPSS 24.00 for windows program was used. Then, the following output is obtained on teble 4.

Table 4. Test Value Significance t

\begin{tabular}{|c|c|c|c|c|c|}
\hline \multicolumn{7}{|c|}{ Coefficients $^{\mathrm{a}}$} \\
\hline \multirow{3}{*}{ Model } & $\begin{array}{c}\text { Unstandardized } \\
\text { Coefficients }\end{array}$ & $\begin{array}{c}\text { Standardized } \\
\text { Coefficients }\end{array}$ & & \\
\cline { 2 - 5 } & $\boldsymbol{B}$ & $\begin{array}{c}\text { Std. } \\
\text { Error }\end{array}$ & Beta & $\boldsymbol{T}$ & \multirow{3}{*}{ Sig. } \\
\hline (Constant) & 605.260 & 64.472 & & 9.388 & .000 \\
\hline
\end{tabular}




\begin{tabular}{|c|l|l|l|l|l|}
\hline Work Discipline & .742 & .245 & .379 & $\mathbf{3 . 0 3 0}$ & .004 \\
\hline $\begin{array}{c}\text { Occupational } \\
\text { Safety \& Health } \\
\text { (OSH) }\end{array}$ & .915 & .268 & .428 & $\mathbf{3 . 4 1 6}$ & .001 \\
\hline
\end{tabular}

Dependent Variable: Employee Performance

The tcount was 3,030 for work discipline and 3,416 for occupational safety and health (OSH). With a significant level $(\alpha)$ of $5 \%$, and degrees of freedom $(v)=$ $42=(\mathrm{n}-(\mathrm{k}-1))$ obtained a table value of 1.681. According to [39], the $t$ test is carried out by comparing the significance of tcount with ttable with provisions:

$\mathrm{HO}$ is accepted and $\mathrm{Ha}$ is rejected if tcount $<$ ttable for $\alpha=0.05$ 0.05

$\mathrm{HO}$ is rejected and $\mathrm{Ha}$ is accepted if $\mathrm{t}>$ ttable for $\alpha=$

Because tcount $>$ ttable or $3.030>1.681$, Ha is accepted, which means that work discipline has a significant effect on employee performance. Occupational safety and health (OSH) $\mathrm{t}$ value is 3,416 . Because tcount $>$ ttable or 3,416>1,681, Ha is accepted, meaning that occupational safety and health (OSH) has a significant effect on employee performance.

Based on the results of the t-test above, it can be concluded that the hypothesis in this study is that $\mathrm{HO}$ is rejected and $\mathrm{Ha}$ is accepted, therefore:

There is a significant influence between work discipline on the performance of employees of PT Kereta Api Indonesia (Persero) Daop 2 Bandung.

There is a significant influence between occupational safety and health $(\mathrm{OSH})$ on the performance of the employees of PT Kereta Api Indonesia (Persero) Daop 2 Bandung.

The $\mathrm{F}$ test was carried out to test whether the independent variable simultaneously affected the dependent variable with a confidence level of $95 \%(\alpha=$ 0.05 ). This test was used to test the significance of the effect of work discipline and occupational safety \& health $(\mathrm{OSH})$ on employee performance of the $\mathrm{F}$ test formula or the ANOVA test described in the following table:

Table 5. Test Value Significance F

\begin{tabular}{|c|l|l|l|c|c|}
\hline \multicolumn{7}{|c|}{ NNOVA $^{\mathrm{a}}$} \\
\hline Model & Sum of Squares & \multicolumn{1}{c|}{$\boldsymbol{d f}$} & Mean Square & $\boldsymbol{F}$ & Sig. \\
\hline \multirow{2}{*}{$\begin{array}{l}\text { Regression } \\
\text { Residual } \\
\text { Total }\end{array}$} & 9958.324 & 2 & 4979.162 & 11.018 & $.000 \mathrm{~b}$ \\
\cline { 2 - 7 } & 18980.876 & 42 & 451.926 & & \\
\cline { 2 - 7 } & 28939.200 & 44 & & & \\
\hline
\end{tabular}

Dependent Variable: Employee Performance

Predictors: (Constant), Occupational Safety \& Health (OSH), Work Discipline
According to [39], the $\mathrm{F}$ test is carried out by comparing the significance of $\mathrm{F}_{\text {calculate }}$ with Ftable with provisions :

$\mathrm{H}_{0}$ is accepted and $\mathrm{Ha}$ is rejected if $\mathrm{F}_{\text {count }}<\mathrm{F}_{\text {table }}$ for $\alpha$ $=0.05$.

$\mathrm{H}_{0}$ is rejected and $\mathrm{Ha}$ is accepted if $\mathrm{F}_{\text {count }}>\mathrm{F}_{\text {table }}$ for $\alpha$ $=0.05$

Based on the above output, the calculated $F_{\text {count }}$ is 11,018 with a p-value (sig) of 0,000 . With $\alpha=0.05$ and degrees of freedom $\mathrm{v} 1=42=(\mathrm{n}-(\mathrm{k}-1))$ and $\mathrm{v} 2=3$, the $F_{\text {table }}=2,827$. Because the value of $F_{\text {count }}>F_{\text {table }}(11,018>$ $2,827)$, then $\mathrm{H}_{0}$ is rejected and $\mathrm{Ha}$ is accepted, meaning that work discipline and occupational safety and health $(\mathrm{OSH})$ together have a significant effect on employee performance.

Based on the results of research on the effect of work discipline on employee performance, it can be concluded that employee performance was positively influenced by work discipline. The amount of direct influence of work discipline on employee performance was $16.2 \%$. This is consistent with research conducted by [1] which showed that work discipline had a partial effect on employee performance.

Based on the results of research on the effect of occupational safety and health on employee performance, employee performance was positively influenced by occupational safety and health. The amount of direct influence on occupational safety and health on employee performance was $20.1 \%$. This is in accordance with research conducted by [40]. The test results showed that occupational safety and health (OSH) partially affected employee performance.

Based on the results of empirical research in the form of the influence of work discipline and occupational safety and health $(\mathrm{OSH})$ on employee performance, it showed that employee performance was influenced by work discipline and occupational safety and health (OSH). The amount of influence directly work discipline and occupational safety and health (OSH) on employee performance was by $34.4 \%$. Thus, it can be concluded that work discipline and occupational safety and health (OSH) had an influence on employee performance. This is also proven by [41] research which showed that simultaneous work discipline and occupational safety and health (OSH) significantly influenced employee performance.

Based on the description, work discipline and occupational safety \& health (OSH) had an influence on employee performance. This means that if work discipline and occupational safety and health (OSH) are good, the optimal work output will be obtained, so that employee performance can improve properly, and ultimately the goals of the organization can be achieved. 


\section{CONCLUSIONS}

Based on the discussion of theory, research results, and multiple correlation analysis tests conducted on the effect of work discipline and occupational safety \& health $(\mathrm{OSH})$ on employee performance, it can be concluded that:

Work discipline had an influence on employee performance. This shows that the higher the work discipline, the higher the performance of the employees of PT Kereta Api Indonesia (Persero) Daop 2 Bandung.

Occupational safety and health (OSH) affected employee performance. This shows that the better the occupational safety and health (OSH), the higher the performance of employees of PT Kereta Api Indonesia (Persero) Daop 2 Bandung.

Work discipline and occupational safety and health (OSH) affected employee performance. This shows that the better work discipline and occupational safety and health $(\mathrm{OSH})$, the higher the employee's performance.

Based on the results of the study, there are some suggestions regarding work discipline and occupational safety and health (OSH) to improve employee performance, which are:

As the results of the study stated that work discipline affected employee performance, thus it is recommended for PT Kereta Api Indonesia (Persero) Daop 2 Bandung to continue to improve effective work discipline to increase the work quality of its employees.

As the results of this study stated that occupational safety and health (OSH) affected employee performance, it is recommended that leaders continue to improve and pay attention to the safety and health (OSH) of their employees by improving the employee's sense of responsibility. The ability to complete tasks in a timely manner shows that the work involved in accountability makes it possible to measure progress, make improvements, and move forward.

The results of this study stated that work discipline and occupational safety and health (OSH) jointly influenced employee performance. Thus, it is recommended that leaders continue to improve work discipline and employees' safety and health so that employee performance can improve.

\section{REFERENCES}

[1] K. Ayu, I. N. Sujana, and A. Zukhri, "Pengaruh kompenasi dan disiplin kerja terhadap kinerja karyawan PT Borwita Citra Prima Cabang Singaraja,” J. Pendidik. Ekon., vol. 10, 2017.

[2] M. Audenaert, A. Decramer, B. George, B. Verschuere, and T. Van Waeyenberg, "When employee performance management affects individual innovation in public organizations: the role of consistency and LMX," Int. J. Hum. Resour. Manag., vol. 30, no. 5, pp. 815-834, 2019.

[3] J. A. Dove, "U . S . state fiscal constraints and railroad development through the nineteenth century nineteenth century," vol. 5522, no. July, 2016.

[4] R. W. S and T. W. S. Panjaitan, "Pengaruh kebijakan keselamatan dan kesehatan kerja terhadap tenaga kerja konstruksi PT Wijaya Karya ( Persero ) Tbk . di Proyek Tol Surabaya Mojokerto," J. Titra, vol. 4, no. 2, pp. 273-278, 2016.

[5] G. Kabir, R. S. Sumi, R. Sadiq, and S. Tesfamariam, "Performance evaluation of employees using Bayesian belief network model," Int. J. Manag. Sci. Eng. Manag., vol. 13, no. 2, pp. 91-99, 2018.

[6] S. H. Senen, Sumiyati, and Masharyono, "The effect of skill variety, task identity, task significance, autonomy and feedback on job performance," vol. 15, pp. 585-588, 2016.

[7] B. L. Nuryanti, M. Masharyono, and H. Fauziatunisa, "The effect of coaching on employee performance," vol. 65, no. Icebef 2018, pp. 136-139, 2019.

[8] K. Sendawula, S. Nakyejwe Kimuli, J. Bananuka, and G. Najjemba Muganga, "Training, employee engagement and employee performance: evidence from Uganda's health sector," Cogent Bus. Manag., vol. 5, no. 1, pp. 1-12, 2018.

[9] I. B. Odunlami and A. O. Matthew, "Compensation management and employees performance in the manufacturing sector, A case study of a reputable organization in the food and beverage industry," Int. J. Manag. Stud. Res., vol. 2, no. 9, pp. 108-117, 2014.

[10] S. H. Senen and N. Triananda, "The employee performance influenced by communication : A study of BUMD in Indonesia," Adv. Econ. Bus. Manag. Res., vol. 15, pp. 596-598, 2016.

[11]B. L. Nuryanti and R. Rahmawati, "The influence of situational leadership and work environment towards employees' performance," vol. 15, pp. 540$543,2016$.

[12]I. Ismail, "Pengaruh kelengkapan alat kerja dan disiplin kerja terhadap kinerja karyawan," J. Stud. Manaj. dan bisnis, vol. 3, no. 1, pp. 90-101, 2016.

[13]A. Wairooy, "Pengaruh disiplin kerja dan kompensasi terhadap kinerja karyawan pada PT . Pertamina (Persero), Tbk . Pemasaran Region VII Makassar,” J. Adm., vol. 4, no. 1, 2017. 
[14] N. Gong, W. F. Boh, A. Wu, and T. Kuo, "Leniency bias in subjective performance evaluation: contextual uncertainty and prior employee performance,” Emerg. Mark. Financ. Trade, vol. 00, no. 00, pp. 1-15, 2019.

[15] I. Putri, H. Wahyu, and D. S. Reni, "Pengaruh budaya kerja, disiplin kerja dan K3 terhadap kinerja karyawan tetap bagian produksi unit spinning 2 pada PT. APAC Inti Corpora,” Ilmu Adm. Bisnis, no. 024, p. 11, 2013.

[16] Y. Suardi, T. Anton, and Suharsil, "Pengaruh disiplin kerja, pendidikan dan pelatihan terhadap kinerja pegawai pada PT Kertas Kraft Aceh (Persero)," J. Saintikom, 2014.

[17] V. A. W. Dapu, "The influence of work discipline, leadership , and motivation on employee performance at PT. Trakindo Utama Manado," J. EMBA, vol. 3, no. 3, pp. 352-361, 2015.

[18] U. S. Muogbo, “The impact of employee motivation on organisational performance (A study of some selected firms in anambra state Nigeria) BY," Int. J. Eng. Sci., vol. 2, no. 7, pp. 70-80, 2013.

[19] T. Atabaki, "From 'amaleh (labor) to kargar (worker): Recruitment, work discipline and making of the working class in the persian/iranian oil industry," Int. Labor Work. Hist., vol. 84, no. 1, pp. $159-175,2013$.

[20] L. Mang, I. Mariani, and N. K. Sariyathi, "Pengaruh motivasi, komunikasi dan disiplin kerja terhadap kinerja karyawan warung mina peguyangan di Denpasar,” E-Jurnal Manaj. Unud, vol. 6, no. 7, pp. 3540-3569, 2017.

[21] K. Huppatz and A. Ross-Smith, "A discipline at the crossroads? Using a gender-inspired paradigm to reposition the sociology of work and employment," J. Sociol., vol. 53, no. 4, pp. 756-770, 2017.

[22] Winaryo and H. Sunaryo, "Pengaruh disiplin kerja dan K3 terhadap kinerja karyawan PT Anugerah Putra Siantan Malang,” J. Ris. Manaj., pp. 103-117, 2016.

[23] A. Moatari-Kazerouni, Y. Chinniah, and B. Agard, "Integrating occupational health and safety in facility layout planning, part I: Methodology,” Int. J. Prod. Res., vol. 53, no. 11, pp. 3243-3259, 2015.

[24]K. Lippel et al., "Legal protections governing the occupational safety and health and workers' compensation of temporary employment agency workers in Canada: reflections on regulatory effectiveness," Policy Pract. Heal. Saf., vol. 9, no. 2, pp. 69-90, 2011.
[25] A. Heryati and R. A. Menzata, "Hubungan antara pendidikan dan pelatihan (diklat) K3 dan pemberian kompensasi terhadap kinerja karyawan PT . Kereta Api Indonesia ( Persero ) Devisi Regional III Palembang,” J. Ekon. Glob., vol. 9, no. 1, pp. 71-76, 2018.

[26] W. Budiawan, Sriyanto, B. Purwanggono, and D. Tauhida, "Pengembangan aplikasi investigasi kecelakaan kereta api berbasis web," Pros. SNATIF, pp. 153-160, 2017.

[27] Ö. Ünal, M. Akbolat, M. Amarat, and S. Tilkilioğlu, "The role of the human factor in occupational safety and health performance,” Int. J. Occup. Saf. Ergon., vol. 0, no. 0, pp. 1-17, 2019.

[28]Z. Pawłowska, "Using lagging and leading indicators for the evaluation of occupational safety and health performance in industry," Int. J. Occup. Saf. Ergon., vol. 21, no. 3, pp. 284-290, 2015.

[29]D. Dejanović and M. Heleta, “An airport occupational health and safety management system from the OHSAS 18001 perspective," Int. J. Occup. Saf. Ergon., vol. 22, no. 3, pp. 439-447, 2016.

[30] M. R. Munandar, E. S. Astuti, and M. S. Hakam, "Pengaruh keselamatan, kesehatan kerja (K3) dan insentif terhadap motivasi dan kinerja karyawan (studi pada pekerja bagian produksi PT. Sekawan Karyatama Mandiri Sidoarjo)," J. Adm. Bisnis, vol. 9, no. 1, pp. 1-9, 2014.

[31] R. W. Mondy and J. J. Martocchio, Human Resource Management, 14th Globa. 2016.

[32]M. Amstrong, Human Resource Management Practice. Great Britian and The United States: Kogan Page Limited, 2016.

[33] R. Veithzal and S. E. Jauvani, Manajemen Sumber Daya Manusia untuk Perusahaan, 6th ed. Jakarta: Raja Grafindo Persada, 2014.

[34]E. Sutrisno, Manajemen Sumber Daya Manusia Jakarta: Kencana Pranada Media Grup. Jakarta: Kencana Pranada Media Grup, 2017.

[35]W. Widodo, "Pengaruh iklim organisasi dan pelaksanaan program K3 terhadap produktivitas kerja PT. Bormindo Nusantara," J. Manaj. Bisnis Krisnadwipayana 3.3, 2015.

[36]J. L. Gibson et al., Las organizaciones: comportamiento, estructura, procesos. México: McGraw-hill, 2011.

[37] N. N, A. L. Tumbel, and J. S, "Pengaruh motivasi, disiplin kerja, kepemimpinan dan kompensasi terhadap kinerja pegawai PT. Adidayah Tangguh di 
Kabupaten Pulau Taliabu,” J. EMBA, vol. 5, no. 3, pp. 4525-4534, 2017.

[38] L. R. Gomez-Mejia, D. B. Balkin, R. L. Cardy, and K. P. Carson, Managing human resources. Upper Saddle River, NJ: Pearson/Prentice Hall, 2007.

[39] I. Ghozali, Application of multivariate analysis with SPSS program. 2011.

[40]F. P. Wibowo and G. Widiyanto, "Pengaruh keselamatan dan kesehatan kerja dan lingkungan kerja terhadap kinerja karyawan bagian produksi pada Perusahaan Tom's Silver Yogyakarta," Primanomics J. Ekon. Bisnis, vol. 17, no. 2, pp. 23 27.

[41] A. O. Hutagalung and Z. F. Ikatrinasari, "Disiplin kerja dan keselamatan \& kesehatan kerja terhadap kinerja karyawan cleaning service PT X di Jakarta (Studi kasus pada Rumah Sakit Mata XYZ)," J. Inkofar, vol. 1, no. 1, pp. 79-90, 2018. 